Dhaka Univ. J. Biol. Sci. 27(2): 201-211, 2018 (July)

\title{
PHYTOAVAILABILITY OF CHROMIUM IN CHROMIUM SALT AND POULTRY FEED
}

\author{
Tazeen Fatima Khan, Samapti Roy and Md. Harunur Rashid* \\ Department of Soil, Water and Environment, University of Dhaka, Dhaka-1000, Bangladesh
}

Key words: Phytoavailability, Chromium, Poultry feed, Tannery waste, Kalmi

\begin{abstract}
A pot-culture experiment was conducted to investigate phytoavailability of chromium in inorganic chromium salt and raw poultry feed made from tannery waste. Poultry feed from tannery waste was applied to the soil at a rate of $5 \mathrm{t} / \mathrm{ha}$ while inorganic chromium salt was applied at a rate of $10 \mathrm{mg} / \mathrm{kg}$ and $810 \mathrm{mg} / \mathrm{kg}$. An upland leafy-vegetable commonly known as Kalmi (Ipomoea aquatica) was used to assess the phytoavailability. Physico-chemical analyses of all soil and plant samples were done at $0,15,30$ and 45 days of incubation to assess chromium phytoavailability and also its effects on the uptake of other heavy metals viz., lead and iron. Plants treated with $\mathrm{Cr}$ showed declined vegetative growth, low accumulation of dry matter, reduced nutrient concentration and reduced nutrient uptake. It was found that the plants accumulated higher amount of $\mathrm{Cr}$ from raw poultry feed treated soil compared to that of the inorganic $\mathrm{Cr}$ salt treated soil. The effect of treatments on $\mathrm{Cr}$ accumulation both in root and shoot was found significant. The study concludes that $\mathrm{Cr}$ is phytoavailable depending on the source and increased concentration of $\mathrm{Cr}$ decreases accumulation of $\mathrm{Pb}$ and $\mathrm{Fe}$ and thereby likely to decrease uptake of these metals.
\end{abstract}

\section{Introduction}

Heavy metal contamination is one of the burning questions of today's modern world because these are gradually taken up by plants and enter into the food chain through plant uptake as well as human and animal consumption. Small and large scale industries release enormous amounts of effluents containing toxic heavy metals particularly chromium ( $\mathrm{Cr}$ ) leading to potential health hazard by its toxic and carcinogenic characteristics $^{(1)}$. Tannery industries have been categorized as one of the highly polluting industries and tannery wastes are characterized by potentially highly toxic $\mathrm{Cr}$ salts and Cr metal ion.

Though $\mathrm{Cr}$ can exist as $\mathrm{Cr}^{2+}, \mathrm{Cr}^{3+}$ and $\mathrm{Cr}^{6+}$, its most stable form is $\mathrm{Cr}^{3+}$ which is relatively immobile and strongly attaches to soil particles ${ }^{(2)}$. In Bangladesh, currently there are 214 tannery industries and among them about 200 are located in the capital city, Dhaka(1-2). Wastes produced in these industries should be treated properly before final

\footnotetext{
*Author for correspondence: <harunur2008@yahoo.com>.
} 
disposal to nearby soil and water bodies. Instead of being treated, the solid wastes are converted into protein enriched poultry feed, fish feed and organic fertilizers due to its high processing $\operatorname{cost}^{(3)}$. It causes leaching of $\mathrm{Cr}$ in the soil making it unfit for agricultural purposes $^{(1)}$. Accumulation of $\mathrm{Cr}$ in plants reduces growth, induces chlorosis and necrosis in young leaves, alters enzymatic functions, causes wilting, plasmolysis in root cells and hampers overall survival of the plants ${ }^{(4)}$.

The uptake of essential nutrient elements by plants is affected by high levels of $\mathrm{Cr}$ accumulation ${ }^{(3)}$. The phytoavailability of $\mathrm{Cr}$ depends on the speciation state and nature of plant species. It was reported that high $\mathrm{Cr}$ associated with the soil components significantly reduce the length of shoot and root of plants and $\mathrm{Cr}$ absorbed by plants remained primarily in the roots and then translocated to leaves ${ }^{(2-4)}$. Consuming $\mathrm{Cr}$ contaminated crops and vegetables may pose a risk to human health. Also, $\mathrm{Cr}$ can enter into the human body through drinking heavy metal contaminated water and by ingesting fishes from contaminated water bodies.

Therefore, the present study was undertaken to assess the accumulation and phytoavailability of $\mathrm{Cr}$ in Kalmi (Ipomoea aquatica) and to assess the effects of $\mathrm{Cr}$ on the uptake of other heavy metals ( $\mathrm{Pb}, \mathrm{Fe}$ and $\mathrm{Mn})$.

\section{Materials and Methods}

Sampling site: The study was carried out in two phases. In the first phase, in vitro incubation study was carried out containing different levels of raw poultry feed and chromium salt produced from tannery wastes. In this case, $500 \mathrm{~g}$ soil samples were taken in each of the plastic pots and treatment was added at different rates. In the second phase, pot culture experiment was conducted with 12 pots in the net-house for growing Kalmi (Ipomoea aquatica) plants. In this case, among the 12 pots, three were supplied with raw poultry feed made from tannery waste and six with chromium salt [potassium dichromate, $\left.\mathrm{K}_{2} \mathrm{Cr}_{2} \mathrm{O}_{7}\right]$ at two different rates.

Representative soil samples were collected from a local vegetative field located at Atigram Union in Manikganj district of Bangladesh (2351.884 N and $\left.90^{\circ} 06.219 \mathrm{E}\right)$. The soil is non-calcareous grey floodplain belonging to the Melandaha series ${ }^{(5)}$.

Soil collection and preparation: The bulk soil sample representing $0-15 \mathrm{~cm}$ depth from surface was collected by the composite sampling method ${ }^{(6)}$. The collected soil samples were dried in air after being transported to the laboratory. Visible roots and debris were discarded followed by gently crushing with a wooden hammer. Ground samples were passed through a $2 \mathrm{~mm}$ sieve which are then stored for both chemical and physicochemical analyses. The bulk soil samples for pot-culture experiment were air dried, cleared off debris, crushed to reduce the size of large clods and screened through a $5 \mathrm{~mm}$ sieve( ${ }^{(7)}$. 
Collection and processing of tannery waste samples: Tannery wastes were collected from different locations of Hajaribagh area of Dhaka. These samples were dried for one week, grinded and finally screened through a $0.25 \mathrm{~mm}$ sieve. For the incubation purpose, top of the pot was cut off, washed properly and dried ${ }^{(8)}$.

Incubation study: Air dried $5 \mathrm{~mm}$ sieved soil sample of $500 \mathrm{~g}$ were taken in plastic pots, treatment was added and then the soils were incubated at field moisture condition for $0,15,30$ and 45 days.

Pot culture experiment: Plastic pots $(120 \mathrm{~mm} \times 145 \mathrm{~mm})$ weighing three $\mathrm{kg}$ having no hole at the bottom were washed thoroughly with water and dried for pot culture experiment. Five $\mathrm{mm}$ sieved soils were mixed with chromium salt and raw poultry feed at a rate of $5 \mathrm{t} /$ ha i.e. each pot containing $1.5 \mathrm{~kg}$ soil received $3.75 \mathrm{~g}$ of raw feed produced from the tannery waste. On the contrary, inorganic chromium salt was added to the soils at a rate of 10 and $810 \mathrm{mg} / \mathrm{kg}$ by using a standard solution of $\mathrm{K}_{2} \mathrm{Cr}_{2} \mathrm{O}_{7}$ (Table 1). The remaining pots were used as control as they were not supplied with any feed and/or salt. Certified seeds of Kalmi, free form disease, pest and harmful weeds, were purchased from local market. Required amount of urea, TSP and MP fertilizers were applied according to the Fertilizer Recommendation Guide ${ }^{(9)}$ as a source of N, P and K, respectively to ensure the optimum growth of Kalmi.

Table 1. Treatment description and symbol.

\begin{tabular}{lccc}
\hline Treatment description & Rate of application & Number of pots & Symbol \\
\hline Control soil & None & $6(2 \times 3)$ & Co \\
Soil + raw poultry feed & $5 \mathrm{t} / \mathrm{ha}$ & $6(2 \times 3)$ & RPF \\
Soil + chromium salt & $10 \mathrm{mg} / \mathrm{kg}$ & $6(2 \times 3)$ & $\mathrm{Cr} 1$ \\
Soil + chromium salt & $810 \mathrm{mg} / \mathrm{kg}$ & $6(2 \times 3)$ & $\mathrm{Cr} 2$ \\
\hline
\end{tabular}

Ten seeds of Kalmi were sown on each pot. After 12 days the seeds began to germinate. Pruning was done and at least five seedlings were kept in each pot and allowed them to grow. The pots were arranged in the net-house in a completely randomized design. Plants were watered with tap water twice daily. Adequate plant protection measures were taken throughout the growth period ${ }^{(7)}$. Positions of the pots were changed every alternative day to allow equal exposure to sunlight.

Collection and processing of plant samples: The Kalmi plants were allowed to grow for 45 days after emergence of the seedlings and then plant sampling was done. Harvesting was done manually by uprooting followed by washing with tap water and distilled water to remove ions/solutes from the roots. The plant samples were then separated into two parts- roots and shoots with a metal scissor. The fresh weights (gm/10 plants) of the collected plant and root samples were recorded. 
Laboratory analyses: Physical, chemical and physico-chemical properties of the soil and plant samples were determined in the laboratory. Particle size analysis was conducted following the hydrometer method ${ }^{(10)}$. Organic carbon was determined by wet oxidation method of Walkley and Black ${ }^{(11)}$. Total nitrogen was determined by Kjeldahl digestion method. Total phosphorous content was determined colorimetrically using spectrophotometer at $490 \mathrm{~nm}$ by developing yellow color with vanadomolybdate. Total potassium was determined by flame analyzer after digesting the samples with ternary acid mixture. Total sulphur content was determined turbidimetrically by spectrophotometer at $420 \mathrm{~nm}$ after digesting with $1 \mathrm{M} \mathrm{HCl}$. However, content of available phosphorous was determined by using Bray and Kurtz (for $\mathrm{pH}<6.0$ ) and Olsen method (for $\mathrm{pH}>6.0$ ), available sulphur by turbidimetric method and available potassium by flame analyzer after extracting with $1 \mathrm{M}$ ammonium acetate. Chromium $(\mathrm{Cr})$, lead $(\mathrm{Pb})$ and iron (Fe) were determined by atomic absorption spectrometer (AAS) after extracting the samples with ternary acid mixture. All the samples were analyzed following the standard procedures ${ }^{(10-11)}$.

Statistical analysis: All data were statistically analyzed by using Microsoft Excel and MINITAB (version 17) Packages.

\section{Results and Discussion}

Background analysis: Laboratory analysis of soil and raw poultry feed made from tannery waste was done for organic carbon, total $\mathrm{N}$, available $\mathrm{P}$, extractable $\mathrm{K}$, extractable $\mathrm{S}$, total $\mathrm{Cr}$ and total $\mathrm{Pb}$. It is apparent from Table 2 that the raw poultry feed made from tannery waste contained higher amounts of nutrients and heavy metals compared to that of the soil sample. The reason could be that tannery waste contains different types of nutrients and its heavy metal contents are generally high.

Effects on soil extractable chromium: Extractable $\mathrm{Cr}$ of soils with all the treatments increased from the initial level during the entire incubation periods. RPF treated soils showed sharp increase than $\mathrm{Cr} 1$ and $\mathrm{Cr} 2$ treated soils. This might be due to the elevated levels of $\mathrm{Cr}$ in raw poultry feed. Fig. 1 elucidated that extractable $\mathrm{Cr}$ concentrations gradually increased with days of incubation and showed highest concentration after 45 days of incubation $(9.46 \mathrm{mg} / \mathrm{kg})$ in the RPF treated soils. Nonetheless, the concentration of $\mathrm{Cr}$ was increased higher in $\mathrm{Cr} 1$ than $\mathrm{Cr} 2$ treated soil. Control soil (Co) showed the lowest rate of increase. Similar findings were reported by Orhue et al.(12) and they observed that the $\mathrm{Cr}$ content of the soil gradually increased with the levels of $\mathrm{Cr}$ treatments.

Effects on total nitrogen: Total nitrogen of the soils for all the treatments increased from initial level during the entire incubation periods. In the first sampling (i.e. 0 day of incubation), total $\mathrm{N}$ content of all the soils was stable at the background level except in raw poultry feed (RPF) treated soils which showed sharp increase $(1292.65 \mathrm{mg} / \mathrm{kg}$ ) 
because of high organic matter as well as total $\mathrm{N}$ contents in raw poultry feed (Fig. 2). In case of 15 and 30 days of incubation, the magnitude of total $\mathrm{N}$ increased gradually in all treatments. In the last sampling, total $\mathrm{N}$ increased in all treatments except $\mathrm{Cr} 1$ treated soil. It was mentioned that when an aerobic soil is submerged, mineralization of organic nitrogen will be radically stopped at ammonia stage because of lack of oxygen to carry out the process via nitrite to nitrate ${ }^{(13)}$. Thus ammonia accumulates in anaerobic soils and gradually increases the nitrogen concentration.

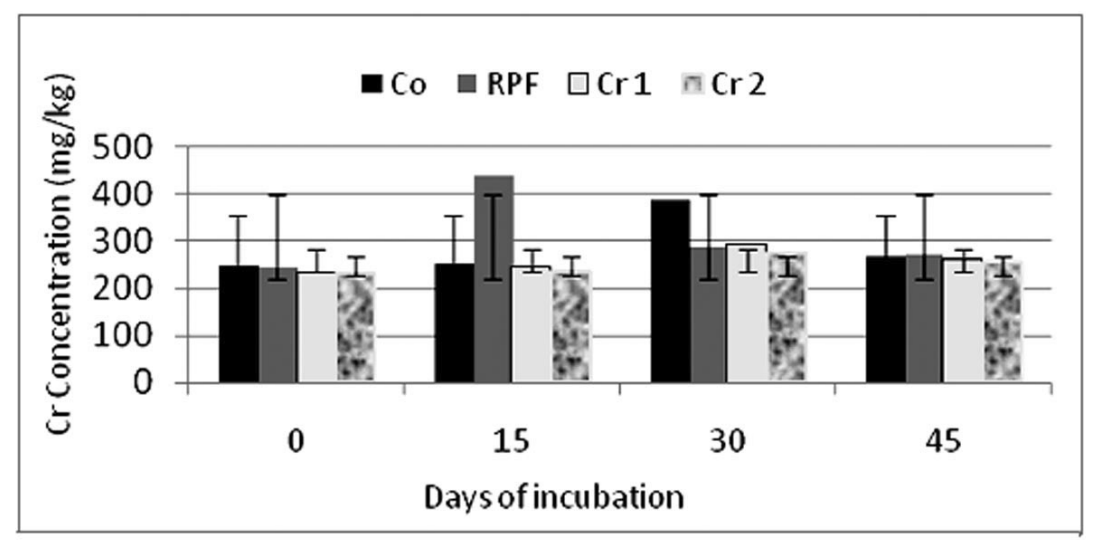

Fig. 1. Effects of raw poultry feed and chromium salt on soil extractable chromium.

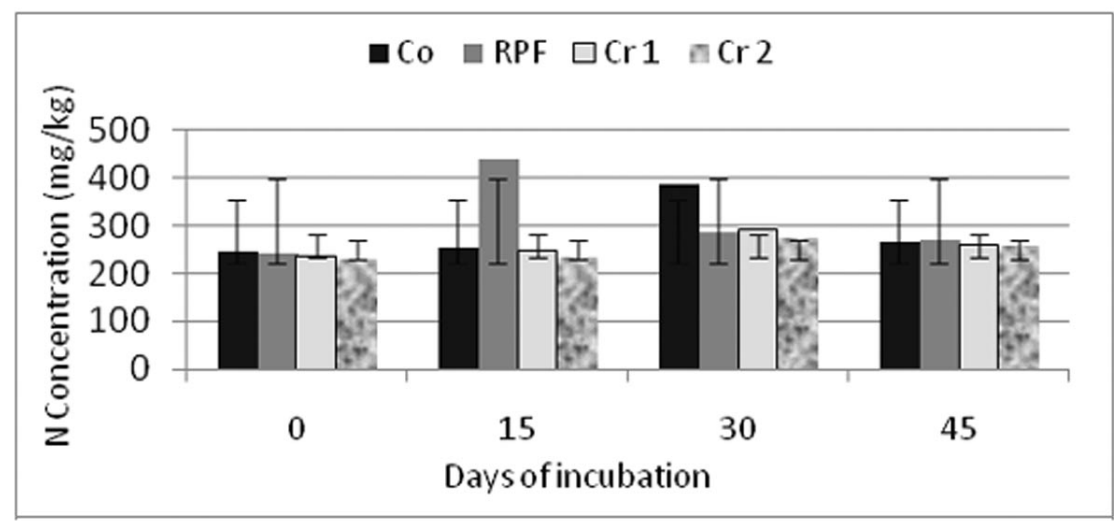

Fig. 2. Effects of raw poultry feed and chromium salt on total nitrogen of soil.

Effects on available phosphorus: After the application of all treatments, soil available $\mathrm{P}$ varied at different incubation periods (Fig. 3). There was no change in the first sampling. At 15 days of incubation, available $P$ in all the soils was increased whereas the soils treated with raw poultry feed (RPF) showed the maximum available $\mathrm{P}(13.09 \mathrm{mg} / \mathrm{kg})$ due to high reduction of phosphate. Addition of organic matter increases the availability of $\mathrm{P}$ 
in RPF. Moreover, available $\mathrm{P}$ was higher in control soil than that of the $\mathrm{Cr}$ treated soils ( $\mathrm{Cr} 1$ and $\mathrm{Cr} 2$ ) as chromium is inhibitory for availability of P. Available P in all soils increased slightly at 30 days of incubation whereas a drastic decline was observed at 45 days except $\mathrm{Cr} 1$ and $\mathrm{Cr}$ 2. Ponnamperuma observed that submergence of soil causes an initial increase in solubility of phosphate due to the reduction of ferric phosphate to ferrous phosphate and subsequently decreases because of readsorbation of phosphate by clay or hydrous oxide of aluminium(13).

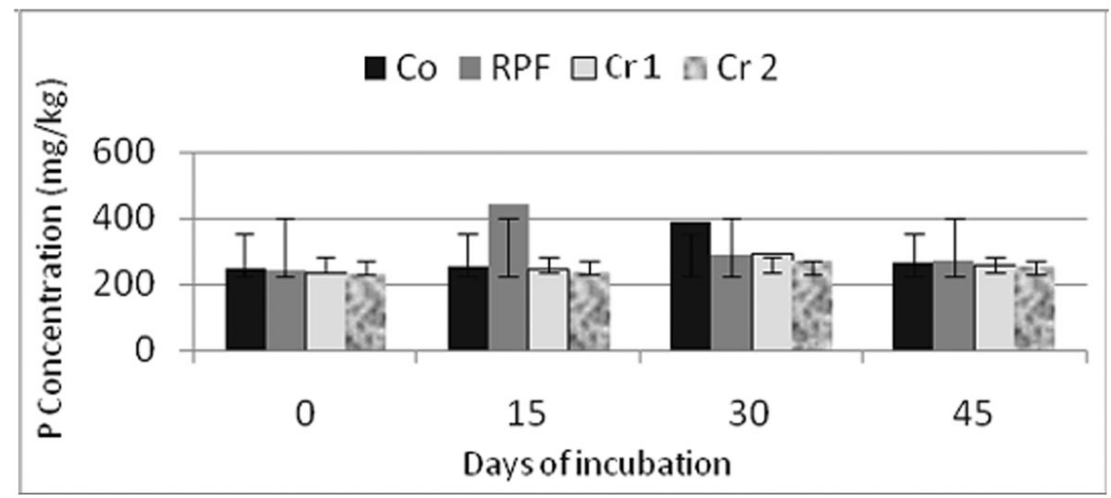

Fig. 3. Effects of raw poultry feed and chromium salt on available soil phosphorus.

Effects on available sulfur: During incubation period, sulfur content in control soil initially increased and then decreased. Sulfur content increased initially followed by a decrease in the soils treated with both raw poultry feed (RPF) and chromium (Cr 1 and Cr 2). Peak concentration of $S$ for RPF treated soil was observed in 15 days of incubation. Available sulfur was higher in control soil compared to that of $\mathrm{Cr} 1$ and $\mathrm{Cr} 2$ as application of chromium is inhibitory for availability of sulfur. Fig. 4 showed that there was a sharp increase in sulfur concentration at the initial stage which was reduced slowly with the days of incubation. It was apparent that available sulfur in chromium salt treated soils and control soil was inconsistent. However, RPF treated soil showed sharp increase initially followed by a gradual decrease during the entire incubation period. This might be due to the presence of sulfur oxidizing bacteria or lack of sulfur reducing bacteria as the soil was slightly acidic ${ }^{(13)}$.

Effects on available potassium: It is apparent from the present study that the available $\mathrm{K}$ of the soils varied at different incubation days (Fig. 5). At the time of first sampling (0 day of incubation), available $\mathrm{K}$ of all treated soils including control (Co) increased from the background level and then decreased gradually. On the contrary, peak concentration of K was observed in poultry feed treated soil (RPF) and chromium treated soil ( $\mathrm{Cr} 2)$ at 0 and 15 days of incubation, respectively. Nagarajan and Sankar ${ }^{(14)}$ revealed four soil 
conditions that markedly influence the amount of $\mathrm{K}$ fixed: (a) nature of soil colloids, (b) wetting and drying, (c) freezing and thawing, and (d) presence of excess lime.

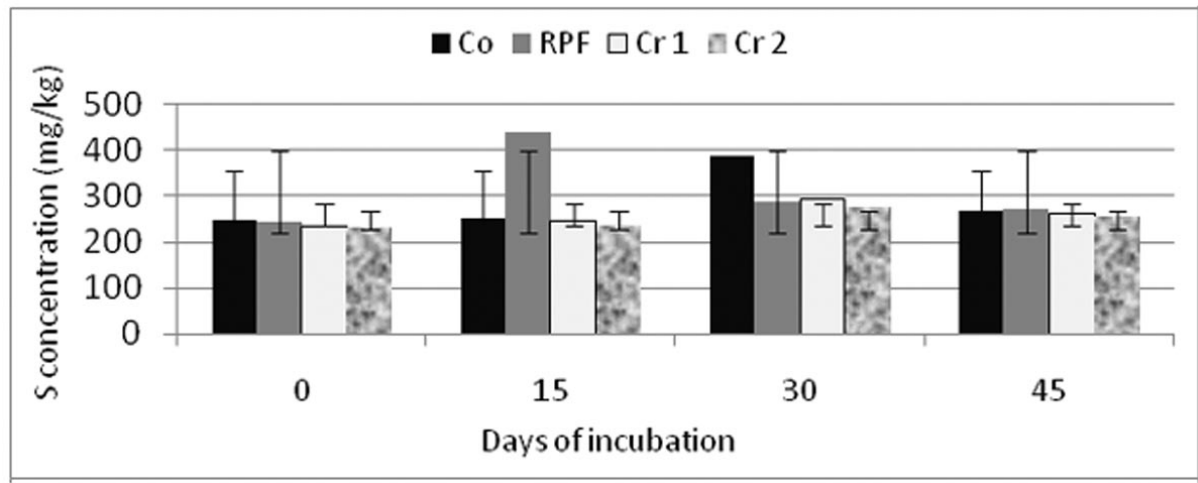

Fig. 4. Effects of raw poultry feed and chromium salt on available soil sulfur.

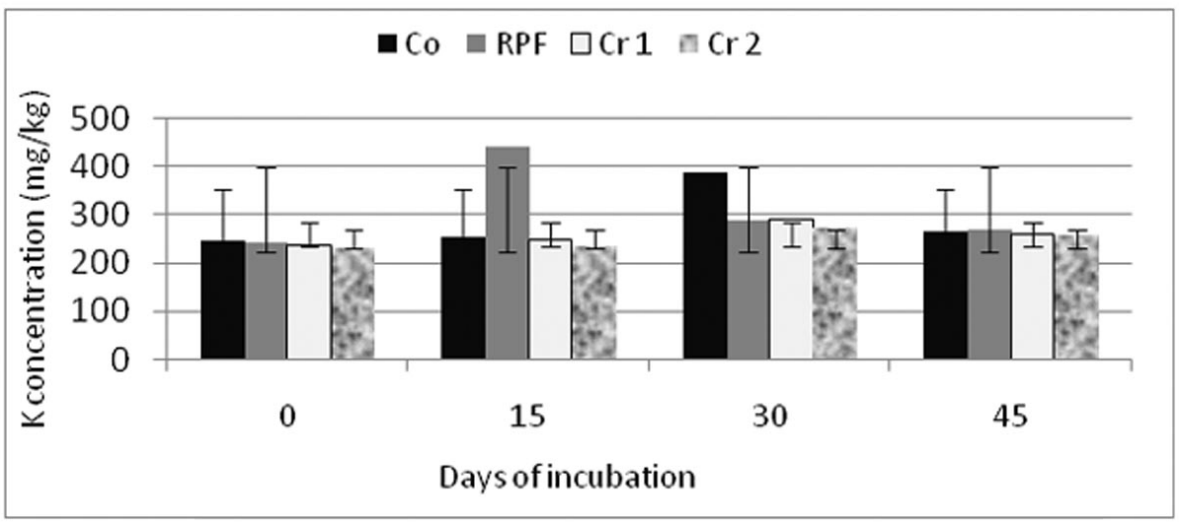

Fig. 5. Effects of raw poultry feed and chromium salt on available soil potassium.

Fresh and dry matter production of Kalmi: It was observed that the growth of Kalmi was best in soils treated with raw poultry feed (Figs 6,7) among all the treatments despite having high $\mathrm{Cr}$ concentration than others. Both the fresh weight and dry weight of shoot was much higher in raw poultry feed treated (RPF) soils (592.27 gm/10 plants and 59.25 gm/10 plants) than the inorganic $\mathrm{Cr}$ salt treated soils ( $\mathrm{Cr} 1$ and $\mathrm{Cr} 2)$. This reason could be the presence of organic matter and other mineral nutrients ( $, ~ P, K, S, C a, M g, F e, M n)$ at high concentrations in raw poultry feed made from tannery wastes ${ }^{(15)}$. Furthermore, fresh and dry weight production is better in $\mathrm{Cr} 1$ than $\mathrm{Cr} 2$ treated soil. $\mathrm{Cr}$ is inhibitory for plant growth and thus, control soil showed higher fresh weight and dry weight production compared to that of $\mathrm{Cr}$ salt treatments. 
The fresh weight of roots showed smaller variations among the treatments compared to the shoots. There was a decrease in growth parameters because of increase in the supply of the Cr. This finding coincides with Mariappan et al.(16) who reported that $\mathrm{Cr}$ accumulation in plants affect the metabolic process in several ways which ultimately leads to decreased growth. Various treatments of treated tannery effluent were found to be toxic because shoot and root length was affected and abnormal structure was observed in the root system. Orhue et al.(12) recorded decrease in dry matter production of Telfairia occidentalis when the concentration of $\mathrm{Cr}$ increased. ANOVA test showed that there was significant effect of the treatments on either the root $(\mathrm{p}<0.001)$ or shoot $(\mathrm{p}=$ 0.001 ) fresh weight productions of Kalmi at $5 \%$ level of significance.

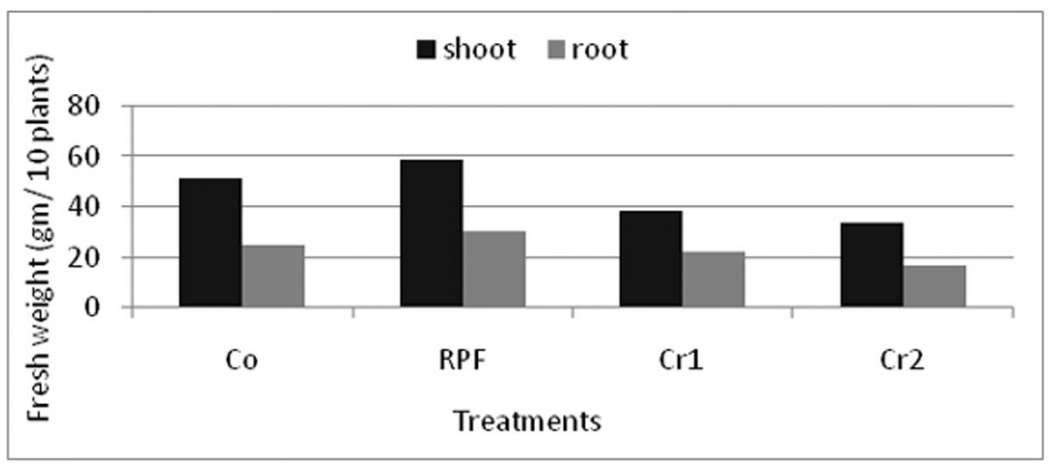

Fig. 6. Fresh weight (gm/10 plants) production of different parts of Kalmi.

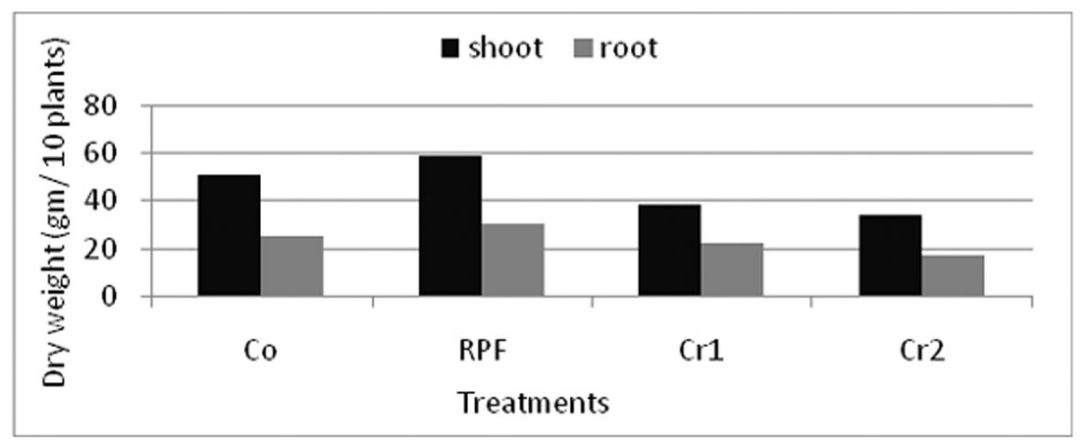

Fig. 7. Dry weight (gm/10 plants) production of different parts of Kalmi.

Accumulation of chromium, lead and iron in Kalmi: $\mathrm{Cr}$ containing raw poultry feed from tannery waste and $\mathrm{Cr}$ salts were applied to the soil to observe their effects on the accumulation of $\mathrm{Cr}, \mathrm{Pb}$ and $\mathrm{Fe}$ in Kalmi plants over the control soil. The concentration and uptake of $\mathrm{Cr}, \mathrm{Pb}$ and $\mathrm{Fe}$ in shoot and root of Kalmi was presented in Table 3. It shows that RPF treated plants accumulated much higher chromium than $\mathrm{Cr} 1$ and $\mathrm{Cr} 2$ 
treated plant. Concentration of $\mathrm{Cr}$ was higher in $\mathrm{Cr} 2$ than $\mathrm{Cr} 1$ but uptake was higher in $\mathrm{Cr} 1$ than $\mathrm{Cr} 2$ treated plants. Both in the root and shoot, the concentration and uptake of Cr was highest in the RPF treated plants and lowest in the control soil plants.

Table 2. Physical, chemical and physico-chemical properties of soil and raw poultry feed.

\begin{tabular}{lccccccc}
\hline \multirow{2}{*}{ Sample } & \multicolumn{1}{c}{ Parameters } \\
\cline { 2 - 8 } & $\begin{array}{c}\text { Total C } \\
(\%)\end{array}$ & $\begin{array}{c}\text { Total N } \\
(\%)\end{array}$ & $\begin{array}{c}\text { Available P } \\
(\mathrm{ppm})\end{array}$ & $\begin{array}{c}\text { Extractable K } \\
(\mathrm{ppm})\end{array}$ & $\begin{array}{c}\text { Extractable S } \\
(\mathrm{ppm})\end{array}$ & $\begin{array}{c}\text { Total Cr } \\
(\mathrm{ppm})\end{array}$ & $\begin{array}{c}\text { Total Pb } \\
(\mathrm{ppm})\end{array}$ \\
\hline Soil & 1.45 & 0.11 & 5.72 & 101.83 & 210.0 & 5.25 & 29.5 \\
$\begin{array}{l}\text { Raw poultry } \\
\text { feed }\end{array}$ & 71.1 & 67.24 & 9400 & 2600 & 5500 & 810 & 195 \\
\hline
\end{tabular}

Table 3. Concentration and uptake of $\mathrm{Cr}, \mathrm{Pb}$ and $\mathrm{Fe}$ in different parts of Kalmi.

\begin{tabular}{|c|c|c|c|c|c|}
\hline \multicolumn{6}{|c|}{ Chromium $(\mathrm{Cr})$} \\
\hline \multirow[t]{2}{*}{ Treatment } & \multicolumn{3}{|c|}{ Concentration (ppm) } & \multicolumn{2}{|c|}{ Uptake ( $\mu \mathrm{g} / 10$ plants) } \\
\hline & Shoot & Root & Total plant & Shoot & Root \\
\hline $\mathrm{Co}$ & 10.06 & 9.33 & 19.39 & 515.48 & 233.44 \\
\hline $\mathrm{RPF}$ & 69.50 & 45.33 & 114.83 & 4117.88 & 1379.40 \\
\hline Cr 1 & 52.83 & 32.83 & 85.66 & 2032.37 & 725.54 \\
\hline $\mathrm{Cr} 2$ & 60.00 & 37.83 & 97.83 & 2038.80 & 653.70 \\
\hline \multicolumn{6}{|c|}{ Lead $(\mathrm{Pb})$} \\
\hline \multirow[t]{2}{*}{ Treatment } & \multicolumn{3}{|c|}{ Concentration (ppm) } & \multicolumn{2}{|c|}{ Uptake ( $\mu \mathrm{g} / 10$ plants) } \\
\hline & Shoot & Root & Total plant & Shoot & Root \\
\hline $\mathrm{Co}$ & 21.5 & 25.83 & 47.33 & 1101.66 & 646.27 \\
\hline $\mathrm{RPF}$ & 8.80 & 36.23 & 45.13 & 521.40 & 1102.48 \\
\hline Cr 1 & 10.93 & 17.83 & 28.76 & 420.48 & 394.043 \\
\hline $\mathrm{Cr} 2$ & 7.83 & 13.17 & 21.00 & 266.06 & 227.58 \\
\hline \multicolumn{6}{|c|}{ Iron $(\mathrm{Fe})$} \\
\hline \multirow[t]{2}{*}{ Treatment } & \multicolumn{3}{|c|}{ Concentration (\%) } & \multicolumn{2}{|c|}{ Uptake (mg/10 plants) } \\
\hline & Shoot & Root & Total plant & Shoot & Root \\
\hline Co & 336.06 & 259.17 & 595.23 & 17219.72 & 6484.43 \\
\hline $\mathrm{RPF}$ & 195.50 & 133.00 & 328.50 & 11583.37 & 4047.19 \\
\hline Cr 1 & 258.33 & 187.33 & 445.66 & 9937.96 & 4139.99 \\
\hline Cr 2 & 209.67 & 162.33 & 372.00 & 7124.59 & 2805.06 \\
\hline
\end{tabular}

Increase in $\mathrm{Cr}$ accumulation was found to be dependent on increase in $\mathrm{Cr}$ doses in the soil. It was found that both the concentration and uptake of $\mathrm{Cr}$ was higher in shoot than that of root. Accumulation of $\mathrm{Cr}$ in control plants was low but those treated with the $\mathrm{Cr}$ had higher levels of the metal making it hazardous to health. Effects of treatment on 
the accumulation of $\mathrm{Cr}$ in root and shoot was found significant $(\mathrm{p}=0.000)$ at $5 \%$ level. Singh et al.(2) applied tannery sludge to tomato plants and found that $\mathrm{Cr}$ mainly accumulated in roots. The $\mathrm{Cr}$ might alter the concentrations of mineral elements in the roots by physically blocking off mineral ions from absorption sites of roots and ultimately reduced mineral uptake with the increase in $\mathrm{Cr}$ doses ${ }^{(17)}$.

It is clear from Table 3 that control soil plants had the highest accumulation of $\mathrm{Pb}$ which might be due to high $\mathrm{Pb}$ contents of soil. Increased rate of $\mathrm{Cr}$ application was found to decrease $\mathrm{Pb}$ accumulation in all plants grown in $\mathrm{Cr}$ treated soil. However, $\mathrm{Pb}$ concentration was higher in RPF treated plants compared to that of $\mathrm{Cr} 1$ and $\mathrm{Cr} 2$ as it contained high amount of $\mathrm{Pb}$ initially. Effects of treatment on the accumulation of $\mathrm{Pb}$ both in root and shoot was found significant $(p=0.000)$ at $5 \%$ level.

Effects of treatments on Fe accumulation was found to be significant ( $p=0.001$ and 0.002 for Fe concentration; $p=0.001$ and 0.001 for Fe uptake) at $5 \%$ level. It is apparent from the study that the increase in $\mathrm{Cr}$ rates reduced accumulation of Fe. Table 3 shows that Fe accumulation was highest in the control plants and lowest in RPF treated plants. Between $\mathrm{Cr} 1$ and $\mathrm{Cr}$ 2, concentration of $\mathrm{Fe}$ was higher in $\mathrm{Cr} 1$. The trend of $\mathrm{Fe}$ accumulation was almost similar to that of $\mathrm{Pb}$ accumulation and thus, increase the rate of $\mathrm{Cr}$ application decreased $\mathrm{Pb}$ accumulation. According to Gopal and Sharma, the concentration of $\mathrm{Fe}$ was decreased due to the presence of high concentration of $\mathrm{Cr}$ which induced Fe deficiency in the crops as there is competition by the heavy metals for functional sites of $\mathrm{Fe}$ binding ${ }^{(18)}$. Decrease in the uptake of nutrients by shoot and root might be attributed to a decrease in nutrient contents as a result of increase in $\mathrm{Cr}$ application ${ }^{(19)}$.

The present study suggests that application of $\mathrm{Cr}$ containing raw poultry feed and inorganic $\mathrm{Cr}$ salt increase $\mathrm{Cr}$ availability gradually with the days of incubation. $\mathrm{Cr}$ application initially increased availability of $\mathrm{N}, \mathrm{P}, \mathrm{K}, \mathrm{S}$ which was decreased with incubation periods. All treatments had negative impacts on the growth of Kalmi except raw poultry feed treated soil. However, plants grown on raw poultry feed treated soil accumulated highest $\mathrm{Cr}$. Increase in $\mathrm{Cr}$ doses decreased the accumulation of $\mathrm{Pb}$ and $\mathrm{Fe}$ and control soil showed the highest accumulation of these heavy metals. Therefore, $\mathrm{Cr}$ containing tannery wastes should be treated well before using it in agricultural soils.

\section{References}

1. Avudainayagam S, M Megharaj, G Owens, RS Kookana, D Chittleborough and R Naidu 2003. Chemistry of chromium in soils with emphasis on tannery waste sites. Rev. Envl. Conta. Toxicol. 178: 53-91.

2. Singh S, S Sinha, R Saxena, K Pandey and K Bhatt 2004. Translocation of metals and its effects in the tomato plants grown on various amendments of tannery waste: evidence for involvement of antioxidants. Chemosphere 257: 91-99. 
3. Caldelas C, JL Araus, A Febrero and J Bort 2012. Accumulation and toxic effects of chromium and zinc in Iris pseudacorus L. Acta Physiologiae Plantarum 34(3): 1217-1228.

4. Shaganas BB, P Thangaval and V Suhburam 1997. Toxicity of neolan grey to Vignaradiata. Pollu. Res. 16(1): 25-28.

5. Rahman MR 2011. Soils of Bangladesh. Darpon Publications, Bangladesh. pp. 127-130.

6. USDA (United States Department of Agriculture) 1951. Soil Survey Manual. Soil Survey Staff, Bureau of Plant Industry, Soils and Agricultural Engineering, United States Department of Agriculture, Washington. Handbook No. 18.

7. Imamul Huq SM and MD Alam 2005. A Handbook on Analyses of Soil, Plant and Water. BACERDU, University of Dhaka, Bangladesh. pp. 1-246.

8. Islam BI , AE Musa,EH Ibrahi , AA Salma and M Babiker 2014. Evaluation and characterization of tannery wastewater. J. For. Produ. Indust. 3(3): 141-150.

9. BARC (Bangladesh Agricultural Research Council) 2005. Fertilizer Recommendation Guide-2005. Publication No. 45. BARC, Dhaka.

10. Carter MR and EG Gregorich 2007. Soil sampling and methods of analysis. 2nd ed. CRC Press, Boca Raton, Florida.

11. Jackson ML 1962. Soil chemical analysis. Prentice Hall, Inc, Englewood Cliffs, New Jersy. pp. 140-157.

12. Orhue, E Robert and U Frank 2010. Phyto-availability of chromium to fluted pumpkin (Telfairi occidentalis Hook F) in an Ultisol. Res. J. Agri. Biol. Sci. 6(6): 716-727.

13. Ponnamperuma FN 1965. The mineral nutrition of the rice plant. Johns Hopkins Press, Baltimore, Maryland. pp. 295-328.

14. Nagarajan M and KG Sankar 2015. Toxic effects of chromium on growth of some paddy varieties. Intl. Letters Natu. Sci. 35: 36-44.

15. Sinclair TR 1992. Mineral nutrition and plant growth response to climate change. J. Expt. Bot. 43(8): 1141-1146.

16. Mariappan V, T Balamurugan and MR Rajan 2001. Irrigational utilization of treated tannery effluent and its impact on growth and some biochemical characteristics of certain crop plants. Ecol. Environ. Cons. 7: 205-210.

17. Beijian M, JD Puryear and RJ Newton 2002. Assessment of $\mathrm{Cr}$ tolerance and accumulation in selected plant species. Plant \& Soil 247(2): 223-231.

18. Gopal R and YK Sharma 2014. Effects of chromium (vi) on groundnut (Arachis hypogeae L.) metabolism. J. Plant Physiol. Pathol. 2: 2.

19. Shahandeh H and LR Hossner 2000. Plant screening for chromium phytoremediation. Int. J. Phytor. 2(1): 31-51. 